D. O. Kulagin 1 , Cand. Sc. (Tech.), Assoc. Prof., orcid.org/0000-0003-3610-4250,

D. V. Fedosha ${ }^{1}$, Cand. Sc. (Tech.), Assoc. Prof., orcid.org/0000-0002-0683-0561,

V.V. Nitsenko², Cand. Sc. (Tech.), orcid.org/0000-0002-3450-7649,

S. Yu. Shevchenko ${ }^{3}$, Dr. Sc. (Tech.), Assoc. Prof., orcid.org/0000-0002-9658-7787,

D. O. Danylchenko ${ }^{3}$,

orcid.org/0000-0001-7912-1849
1 - Zaporizhzhya National Technical University, Zaporizhzhia, Ukraine, e-mail: kulagindo@gmail.com

2 - State Enterprise "National Power Energy Company "Ukrenerho", Regional dispatching center of Dnipro region, Zaporizhzhia, Ukraine, e-mail: nicenkovladimir@gmail.com 3 - National Technical University "Kharkiv Politechnical University”, Kharkiv, Ukraine, e-mail: danylchenko.e@khpi.edu.ua

\title{
USING A PHASE-DIFFERENTIAL BUSBAR PROTECTION FOR SWITCHGEARS OF POWER SYSTEM FACILITIES
}

Purpose. To develop a concept for the implementation of a more advanced device designed for the busbar protection of power plants and substations which has advantages in technical operation over its traditional analogs by applying the phase-differential principle of this protection.

Methodology. When developing the concept of implementation of phase-differential busbar protection, we used the method of comparative analysis, in particular, a qualitative analysis of the characteristics of busbar protection was carried out; difficulties encountered in the operation of traditional differential protection as well as advantages that can be obtained by introducing phasedifferential protection were considered in the work.

Findings. Based on many years' experience in the operation of differential current protection at power system facilities, the problematic issues of its operation are identified. We suggest using the phase-differential principle for busbar protection operation; its distinctive features are distinguished in comparison with traditional protections. The conditions for starting, tripping and returning of the phase-differential protection are determined, and there is suggested a method for determining the sensitivity of phase relay concerned to the angle. The phase characteristic of the protection is shown, which is the major operating characteristic which determines the width of the working zone and the blocking of this protection type.

Originality. For the first time, use of phase-differential busbar protection, the principle of which is based solely on comparing the phases of the secondary currents of bays, connected to the common busbar system, has been suggested. At the same time, there is no provision for the use of any additional protection relays, which can provide a protection starting and use a different principle of operation from the phase-differential one.

Practice value. The phase-differential busbar protection relay can be accepted into the technical operation in the power system facilities as an alternative option of using the traditional differential current protection. It has a number of advantages and allows solving existing problems of protection operation caused by increased requirements for current transformers in differential busbar protection circuits, necessity of tedious calculations of its, рабочих уставок, information redunancy and complexity of modern digital relays, which perform the function of phase-differential protection.

Keywords: phase-differential busbar protection, differential current protection, switchgear, busbar, relay protection

Introduction. In accordance with the requirements [1], all power equipment of power plants and substations, overhead and cable lines must be protected against short-circuit (SC) and disturbance of their normal operations by the relay protection devices (RPD), in which the execution program and settings of RPD must correspond to the actual schemes and modes of operation of power system.

The high-voltage and extra-high-voltage switchgear busbars of power plants and substations are one of most important and responsible of their elements, because through busbars there incessantly occurs emission of electrical power, generated at power plants, its transits through busbars of huge node substations, with the following distribution to the districted units of power system, the distributing mains, and to the local loads, which get supply directly from busbars. Busbar damage, as a rule, has a rather difficult pattern, as it is accompanied by the flow of high currents of large multiplicities and the deep descend of voltage of particular nodes of power system and consumer, thus, it leads to the disturbance of normal operation mode.

All mentioned above determines tough requirements [2] to the devices of relay protection for busbars (RPB), particularly:

- high rate of switch-off of the damaged busbars, which allows ensuring an efficient dynamic stability margin of the power system, preventing damage power, switching and mea-

(C) Kulagin D.O., Fedosha D.V., Nitsenko V.V., Shevchenko S. Yu., Danylchenko D. O., 2019 suring equipment, post insulators, bus conductors, and also allows partial or full restoration of the pre-emergency mode (restoring power transit, supplying consumers who do not have the power supply reserve);

- high sensitivity in normal, post-emergency and repair modes of the switchgears, and, in particular, in manual or automatic mode of switch-on of the busbars on the stable shortcircuit and other similar modes, accompanied by a sharp decreasing level of short-circuit current [3];

- single switch-on the busbars on the stable short-circuit;

- ensuring reliable detuning from steady-state and transient differential unbalance currents in emergency modes;

- compulsory use of the device for automatic check integrity of current circuits RPD and blocking execution of RPD if current circuits are damaged; delay.

- selective switch-off of the damaged busbars without time

At present time, as a set of the main RPB devices are used whose principle is based on determining geometrical sum of currents of connection points - a device of differential busbar protection (DBP). These devices, in our view, have some imperfections, which under certain operating conditions and modes of power system can work in the wrong way (work falsely, unnecessarily or fail).

Among these imperfections the following are to be distinguished:

- lack of sensitivity of the start-selector units of DBP when internal short-circuit occurs with minimal levels of emergency 
currents, it leads to the need to use an additional current sensor in the protection, which is switched on after the DBP execution is completed and when manual mode of switch the busbars occurs;

- probability of nonselective execution of DBP in case of the emergency modes, which are accompanied by saturation of the magnetic cores of the measuring current transformers (MCT), whose secondary circuits are connected to DBP, and in case of the compromised integrity of the secondary circuits MCT, which requires the use of additional means to prevent the occurrence of above cases and responding to their occurrence;

- complication and bulkiness of the existing methods for calculating the settings of busbars' RPD, and the need of periodic review of settings in case of change in the mode of electric installation and adjacent mains, however, in practice, this procedure is not performed or does not work properly;

- in some cases, it is difficult to select the settings of DBP due to the protection tuning from maximal value of the passing currents of unbalance and ensuring $10 \%$ of full error of MCT in the emergency modes, which restricts the conditions of operating MCTs;

- when different types of MCTs are used in DBP current circuits, particularly with different transformation ratios, it becomes necessary to balance the secondary currents of these MCTs to exclude occurrence of the unbalance current in the differential protection circuit in normal mode, which additionally introduces some errors in the measuring circuit and reduces its reliability.

Modern digital DBP devices are more reliable and convenient in operation than their predecessors - electromechanical and semiconductor protections. They are largely hassle free unlike their predecessors, but according to prof. Gurevich [3], their main disadvantages are technical and informational redundancy, and, in particular, it is a fairly large amount of information entered into them: parametric setpoints, internal logic configuration, complex and voluminous guidelines for setting up and operating these devices.

Computation and adjustment of the working settings of digital DBP is indeed quite time-consuming and complicated procedure and requires highly qualified personnel for performing these types of work. At the same time, at each stage of commissioning digital DBP devices, there is probability of errors made by personnel, which can later result in an incorrect operation of these devices. According to the research by prof. Gurevich [3], namely, errors in the setpoints and settings of digital RPD rank high and account for about $40 \%$ of the total number of causes of their malfunction.

Relevance. In this regard, at present, a rather relevant task is the development and practical implementation of new scientific and technical solutions to improve the constructive and functional base of the RPB; the purpose of development is to increase the reliability, selectivity, protection sensitivity, and reduce the probability of its false, unnecessary work or failure.

Purpose. To develop a concept for implementation of more advanced RPD of busbars, which has advantages in technical operations over their traditional analogs, by applying the phase-differential principles of busbar protection.

Results. We analyzed the existing drawbacks of the DBP, separately from the hardware construct, and came to the conclusion that further improvement of devices, done by the differential current operation principles, is inappropriate.

As an alternative option to solve the problem of ensuring reliable protection of the busbar, with absolute selectivity, we propose the implementation of a phase-differential principle of busbar protection based on a digital RPD, which is based on the algorithm for comparing the current phases of the connections, connected to the common system of the busbar. Earlier, we have already considered in detail the method for performing measuring, logic and output circuits of phase-differential bus protection (PDBP), and a principle of its functioning [4].
In this paper, we want to focus on the main features of the implementation of the PDBP using the algorithm for comparing the phases of the currents compared to the traditional DBP with dynamic braking and sensitive current unit. We will also consider the conditions for starting, triggering and returning protection, a possible way to determine its sensitivity by angle.

Note that, the PDBP does not contain any other measuring and start-up units, except for the phase units - the relay for comparing the phases of currents; therefore, conditions for starting, triggering and returning protection will be determined based only on the ratio between the phases of the connection currents (their angular shift), which, as it is known, in the "ideal case" is 0 degrees with internal SC, and with external $\mathrm{SC}$ and other modes it is close to 180 degrees.

Such a concept of design of the RPB has its own characteristics in comparison with known protections provided by the differential current principle of operations, among them are the following:

- use of an integrated algorithm for comparing the current phases to achieve an absolutely selective RPB, which does not respond to the absolute values of emergency currents and, according to the principle of operation, adjusted from the current errors of MCTs, which vary to a much greater degree than their angular errors [5];

- selectivity of PDBP performance in all modes (including emergency) is achieved by selecting and setting only one working value $-\varphi_{b l}$ protection blocking angle; the protection has one working phase characteristic (analogous to DBP braking characteristic) [5];

- PDBP has 2 basic settings: blocking angle $\varphi_{b l}$ (to distinguish internal SC from other modes of mains) and the level of formation of pulses $i_{y}$ (used in the phase modulation process $[4,5])$;

- PDBP start-up in short-term match of current phases of connections, due to some disturbance that has caused current reversal in one or several phases (or due to distortion of the secondary current of one or several connections), and the protection is triggered only when confirming the long-term synphasis of these currents for some time specified by the control setpoint (characteristic only for internal SC or damage of current circuits with the loss of the "blocking signal");

- use of the compensation algorithm for angular errors, saturated MCTs, which can reach up to $7 \mathrm{~ms}$ (126 degrees for the current through the "zero") and more, depending on the parameters of the power supply system and the parameters of MCT, the sign and the value of the residual induction of magnetization, etc. [6, 7];

- in design and principle, the protection is not identical to the phase-differential protection of $110-750 \mathrm{kV}$ overhead lines (DPLP) [3], significant differences are due to the feature of the protected object and the rejection of using the starting unit by current and distance unit; the phase modulation process also has certain peculiarities in connection with the implementation of the algorithm for compensation of angular errors for the saturated MCTs [8];

- dead-end connections (which do not supply a short-circuiting) and low-power connections do not affect the determination of ratios between the current phases of connections by the phase-differential busbar protection [9].

Consider the basic conditions for starting, tripping and returning the PDBP.

The condition for starting and tripping the protection is as follows

$$
\Delta \varphi_{\max }<\left(180-\varphi_{b l}\right),
$$

where $\Delta \varphi_{\max }$ is the limiting angle of divergence of the currents of the connections that are connected to the common busbar system, determined by the influence of a number of factors of the mains, more detailed in [6]; $\varphi_{b l}$ is the setting of the blocking angle of protection, which, according to [10], is recommended to apply 90 degrees. 
Provided $\Delta \varphi_{\max }=\varphi_{b l}$ the protection is on the edge of its tripping.

The phase (angular) characteristic of PDBP, which determines the width of the zone of tripping and blocking of the protection in accordance with the selected blocking angle setting $\varphi_{b l}=90^{\circ}$, is shown in Figure.

As can be seen from Figure, the phase characteristic is fairly simple and intuitive, which simplifies the understanding of the principle of such protection by personnel, so the PDBP will be tripping, if vectors of the secondary current of connections connected to the common busbar system are located within the working area $\left[0^{\circ} ; 90^{\circ}\right) \cup\left(270^{\circ} ; 360^{\circ}\right]$ on the phase characteristic. Otherwise, if one or several vectors of secondary current of connections will be located within the blocking zone on the phase characteristic of PDBP $\left[90^{\circ} ; 270^{\circ}\right]-$ the protection will be blocked.

The condition for returning the protection is as follows

$$
\Delta \varphi_{\max } \geq k_{r} \cdot \varphi_{b l},
$$

where $k_{r}$ is the returning coefficient of the protection, which can be equal to 1.05-1.1, but it needs to be clarified after carrying out laboratory tests of the PDBP.

We also note that the determination of the sensitivity of PDBP is not an easy task, since the required methodologies that allow one to quantify the sensitivity of this type of the relay protections are absent. Consequently, it is necessary to develop a new technique, with the help of which it is possible to evaluate the sensitivity of protections incorporating only the phase starting units that react to the relationships between the phases of secondary currents of several sets of MCTs.

We propose to evaluate the sensitivity of PDBP by angle using the concept of the sensitivity coefficient of the protection, which corresponds to the current requirements [2], according to the following expression

$$
K_{S}=\frac{\text { setpoint }}{\text { controlled parameter }} .
$$

Expression (3) is a characteristic for estimating the sensitivity of the minimum protections, that is, those protections that react to a decrease in the value of the monitored parameter and perform, when this value becomes less than its operating setting, for example, remote protections or undervoltage protections.

For PDBP sensitivity coefficient can be estimated in p.u. by the following expression

$$
K_{S}=\frac{180-\varphi_{b l}}{\Delta \varphi_{\max }} \geq 1.2,
$$

where $\Delta \varphi_{\max }$ is the limit angle of divergence of the vectors of currents of connections connected to the common busbar system at the time of disconnecting the internal SC:

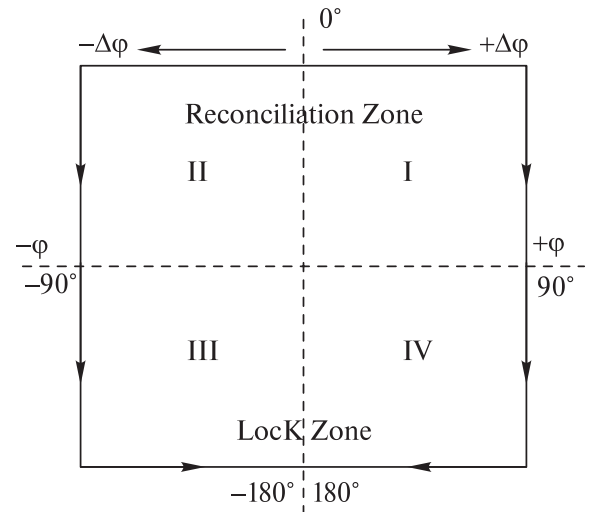

Fig. Phase characteristic of PDBP with a set angle of blocking of 90 degrees

$$
\Delta \varphi_{\max }=f\left(\Delta \delta_{T C}, \Delta \delta_{D A C}, \Delta \delta_{M}, \Delta \delta_{I M P}\right),
$$

where $\Delta \delta_{T C}$ are angular errors of MCTs; $\Delta \delta_{D A C}$ is an angular error of analog-digital conversion of periodic currents; $\Delta \delta_{M}$ is a limit angle of divergence of the EMF vectors of generators of connections that supply SC on busbar; $\Delta \delta_{I M P}$ is the difference between the impedance angles of different types of connections, for example: a line and a power transformer.

This technique allows us to estimate the sensitivity of the PDBP in each specific case for a specific electrical installation depending on the existing parameters of the power system mode and the above factors, according to expression (5). Under the condition of choosing the working setting of the protection blocking equal to 90 degrees, the minimum sensitivity of the PDBP in all of the power system modes will be provided with the sensitivity coefficient $K_{S}=1.2$, which will provide an additional margin of the protection sensitivity in the minimal internal SC modes, provided that it is offset from the influence of the angular errors MCTs and other factors considered above.

The advantages of using phase-differential busbar protection. Let us pay attention to the benefits that the use of PDBP allows obtaining in comparison with traditional DBP with dynamic braking and the sensitive currents unit:

- the selectivity of the protection action is achieved by selecting only one design setpoint - the protection blocking angle, which determines the width of the protection failure zone (by angle) in its phase characteristic;

- the possibility of using the adaptive parametric setpoints of the protection (set "in the factory state" by the manufacturer of the relay protection device and taking into account the maximum influence of mains' factors that may lead to nonselective perform);

- sufficient sensitivity of protection is provided without the use of an additional sensitive current unit (KS not less than 1.2 in all design modes of the power system) and does not depend on the frequency of the emergency current; PDBP adjustment is done only from the angular errors of MCT, which are not normalized by state standard of Ukraine and change to a lesser extent than current ones, while the current errors do not affect the protection performance and do not lead to a violation of its selective work, which excludes the concept of "unbalance current", from which adjust traditional DBP;

- protection allows saturation of the MCTs and their operation with increased errors, absolute selectivity of PDBP at saturation of the MCTs is provided by using the algorithm for compensation of angular errors of saturated MCT, which is implemented in the pulse shapers, which perform phase modulation of the converted analog signals of currents [5];

- the feasibility of using the protection in primary switchgear circuits with heterogeneous types of the MCTs, in particular, having different transformation ratios, without the need to balance their secondary currents and compensate (limit) the measurement errors arising in the process of perform;

- reducing the probability of false actions of protection in damage of current circuits of the MCTs of one of the connections with concomitant failure node failure detection of these chains (false action of PDBP is possible only in case of loss "signal of blocking" - the current being in antiphase to the currents of other connections, e.g., the current in the damaged connection with external SC);

- prospective protection of other elements of mains with concentrated electrical parameters (transformers and autotransformers, reactors, high-power electric motors);

- universalism of application: primary switchgears of any configuration with a class of voltage of $110 \mathrm{kV}$ and above for power stations and substations, lack of functional limitations; all restrictions for the use of PDBP are determined only by the design of the digital device and the requirements for processing analog signals; 
- an alternative solution was proposed for use in the modern digital DBP of the blocking by the $2^{\text {nd }}$ and $5^{\text {th }}$ harmonics. The use of such a blocking in the PDBP is not desirable, since with an internal short circuit with the MCT saturation (this mode is not excluded), the level of the main harmonic in the differential current can sharply decrease, while the $2^{\text {nd }}$ harmonic increases, therefore, the ratio of the $2^{\text {nd }}$ harmonic to the $1^{\text {st }}$ may exceed the blocking setting and unnecessarily block the protection with braking. The current for the operation of the differential cutoff in this mode may also be insufficient (due to saturation of the MCT), which will lead to a failure of the DBP. An alternative solution is the use of the blocking device that responds to aperiodic magnetizing current surges, which are transformed into the secondary MCT circuits, which are detected by two of its characteristic features: the presence of non-current pauses and the absence of unipolar half-waves in the secondary current.

Conclusions. Thus, we considered the possibility of implementing a new type of relay protection for busbars for switchgears of power stations and substations, and also formulated a concept for the implementation of protection, highlighting the main features of PDBP in comparison with their traditional protections.

These distinctive properties of PDBP allow obtaining the following positive results in terms of the technical operation of such devices:

- reducing the requirements for the technical characteristics and operating conditions of the MCT (maximum multiplicity, accuracy class, nominal secondary load), which will allow making the secondary MCTs circuits of greater length (relevant for $330-750 \mathrm{kV}$ open switchgear), as well as reducing the cross-section of cable connections, reducing thereby the cost of the project;

- partially eliminating the influence of the human factor on the work of RPD (more than $60 \%$ of incorrect cases occur due to mistakes of design, installation and commissioning and operating by the organization personnel), simplifying protection setpoints, reducing their number and making them adaptive (taking into account the maximum influence of factors from (5) to performance of the protection), getting rid of the complex dynamic characteristics of the protection of busbars with several sections;

- increasing the sensitivity of protection in the minimum modes of the power grid (emergency, maintenance, with automatic and manual testing of tires with voltage, failure of the supply connection switch), omitting an additional sensitive current unit (protection is started even if the current phases are briefly coincident, while tripping occurs only if confirmation long synphase of these currents);

- partially automating, simplifying, and, consequently, reducing the cost of designing protection and its technical operation, eliminating the need to compute the settings (or significantly reducing the volume of these computations), the need for adjusting them, performing planned and unscheduled revisions of the settings (or significantly reducing the amount of these works);

- increasing the reliability of protection for failure and resistance to steady-state and transient unbalance currents in case of through-fault, aperiodic surge of magnetizing current, violation of current protection circuits (by the principle of operation, the protection does not respond to the absolute value of the differential current of unbalance);

- if necessary, implementing distributed busbar protection with installation of local measuring units for each connection to the busbar and transferring information about the current phase of these connections via optical communication channels to the central module that implements the basic logical operations for determining the location of damage.

\section{References.}

1. Technical operation of power plants and networks. Rules (2003). Kyiv: NTUKTs.
2. Rules of electrical. Head 3.2. Relay protection (2015). Kyiv: NPTSR.

3. Gurevich, V. (2006). Microprocessor protection relays: new prospects or new problems? Electrotekhnika i Electromekhanika, 3, 18-26.

4. Kulagin, D. O. (2014). Mathematical model of traction of asynchronous engine taking into account saturation of magnetic circles. Naukovyi Visnyk Natsionalnoho Hirnychoho Universytetu, 6, 103-110.

5. Kulagin, D. O. (2014). Mathematical model of traction asynchronous engine taking into account saturation. Tehnicna elektrodinamika, 6, 49-55.

6. Gurevich, V.A. (2006). Problem of Power Supply of Microprocessor-based Protective Relays in Emergency Mode. Electricity Today Transmission \& Distribution Magazine, 8, 32-36.

7. Podshivalin, A., Klimatova, I., \& Terentyev, E. (2009). Modern Fault Location Technique for the Utility. In Proc. Int. Conf. IEEE Bucharest PowerTech. Bucharest, Romania, DOI: 10.1109/PTC.2009.5282019.

8. Pereira, C.E., \& Zanetta, L. C. (2004). Fault location in transmission lines using one-terminal postfault voltage data. IEEE Transactions on power delivery, 19(2), 570-575.

9. Brahma, S. M., \& Girgis, A.A. (2004). Fault location on a transmission line using synchronized voltage measurements. IEEE Transactions on power delivery, 19(4), 1619-1622. DOI: 10.1109/TPWRD.2003.822532.

10. Kjolle, G., Aabo, Y., \& Hjartsjo, B. (2002). Fault Statistics as a Basis for Designing cost-effective Protection and Control Solutions. SIGRE, Session, 1-6.

\section{Застосування диференційно-фазного захисту шин розподільчих установок об'єктів електроенергетики}

\section{Д. О. Кулагін ${ }^{1}$, Д. В. Федоша ${ }^{1}$, В. В. Ніценко С. Ю. Шевченко ${ }^{3}$, Д. О. Данильченко ${ }^{3}$}

1 - Запорізький національний технічний університет, м. Запоріжжя, Україна, e-mail: kulagindo@gmail.com 2 - Державне підприємство „Національна енергетична компанія „Укренерго“, Регіональний диспетчерський центр Дніпровського регіону, м. Запоріжжя, Україна, e-mail: nicenkovladimir@gmail.com

3 - Національний технічний університет „Харківський політехнічний інститут“, м. Харків, Україна, е-таil: danylchenko.e@khpi.edu.ua

Мета. Розробити концепцію з реалізації більш досконалого пристрою, призначеного для релейного захисту збірних шин розподільчих установок електричних станцій і підстанцій, що матиме певні переваги в технічній експлуатації перед його традиційними аналогами, шляхом застосування диференційно-фазного принципу дії цього захисту.

Методика. При розробці концепції з імплементації диференційно-фазного захисту шин застосовано метод порівняльного аналізу, а саме проведено якісний аналіз характеристик релейного захисту збірних шин, визначені труднощі, що виникають при експлуатації традиційних диференційних струмових захистів, і переваги, які можуть бути отримані при впровадженні диференційнофазного захисту, наявність яких обумовлена його особливостями, розглянутими в роботі.

Результати. На підставі багаторічного досвіду експлуатації диференційних струмових захистів на об'єктах електроенергетичної системи були встановлені проблемні питання їх експлуатації. Запропоноване використання диференційно-фазного принципу дії захисту шин, виділені його відмінні риси в порівнянні із традиційними захистами. Визначені умови пуску, спрацювання й повер- 
нення диференційно-фазного захисту шин, а також запропоновано спосіб визначення чутливості його фазного органу за кутом. Наведена фазна характеристика захисту, яка $є$ його основною робочою характеристикою, що визначає ширину зони спрацювання та блокування захисту.

Наукова новизна. Уперше запропоновано застосувати диференційно-фазний захист шин, принцип дії якого заснований виключно на порівнянні фаз вторинних струмів приєднань, підключених до спільної системи збірних шин. При цьому не передбачається застосування будьяких додаткових пускових органів захисту, що виконані за відмінним принципом дії від диференційно-фазного.

Практична значимість. Пристрій диференційно-фазного захисту шин може бути впроваджений у технічну експлуатацію на об'єктах електроенергетичної системи як альтернативний варіант застосуванню традиційних диференційних струмових захистів. Він має низку переваг і дозволяє вирішити існуючі проблеми експлуатації захистів, обумовлені підвищеними вимогами до вимірювальних трансформаторів струму в колах диференційного захисту шин, необхідністю виконання громіздких розрахунків його робочих уставок, інформаційною надлишковістю та складністю сучасних цифрових пристроїв, що виконують функцію диференційного захисту шин.

Ключові слова: диференційно-фазний захист шин, диференційний струмовий захист шин, розподільча установ$\kappa a$, збірні шини, релейний захист

\section{Использование дифференциально-фазной защиты шин распределительных установок объектов электроэнергетики}

\section{Д. А. Кулагин ${ }^{1}$, Д. В. Федоша ${ }^{1}$, В. В. Ниценко ${ }^{2}$, С. Ю. Шевченко ${ }^{3}$, Д. А. Данильченко}

1 - Запорожский национальный технический университет, г. Запорожье, Украина, e-mail: kulagindo@gmail.com 2 - Государственное предприятие „Национальная энергетическая компания „Укрэнерго“, Региональный диспетчерский центр Днепровского региона, г. Запорожье, Украина, e-mail: nicenkovladimir@gmail.com

3 - Национальный технический университет „Харьковский политехнический институт“, г. Харьков, Украина, e-mail: danylchenko.e@khpi.edu.ua

Цель. Разработать концепцию по реализации более совершенного устройства, предназначенного для релейной защиты сборных шин распределительных установок электрических станций и подстанций, обладающего преимуществами в технической эксплуатации перед его тра- диционными аналогами, путем применения дифференциально-фазного принципа действия этой защиты.

Методика. При разработке концепции имплементации дифференциально-фазной защиты шин использован метод сравнительного анализа, а именно проведен качественный анализ характеристик релейной защиты сборных шин, определены трудности, возникающие при эксплуатации традиционных дифференциальных токовых защит, и преимущества, которые могут быть получены при внедрении дифференциально-фазной защиты, наличие которых обусловлено ее отличительными свойствами, рассмотренными в работе.

Результаты. На основании многолетнего опыта эксплуатации дифференциальных токовых защит на объектах электроэнергетической системы были установлены проблемные вопросы их эксплуатации. Предложено использование дифференциально-фазного принципа действия защиты шин, выделены ее отличительные особенности по сравнению с традиционными зашитами. Определены условия пуска, срабатывания и возврата дифференциальнофазной защиты шин, а также предложен способ определения чувствительности ее фазного органа по углу. Приведена фазная характеристика защиты, которая является ее основной рабочей характеристикой, определяющей ширину зоны срабатывания и блокирования защиты.

Научная новизна. Впервые предложено использование дифференциально-фазной защиты шин, принцип действия которой основан исключительно на сравнении фаз вторичных токов присоединений, подключенных к общей системе сборных шин. При этом не предусматривается применение каких-либо дополнительных пусковых органов защиты, использующих отличный принцип действия от дифференциально-фазного.

Практическая значимость. Устройство дифференциально-фазной защиты шин может быть внедрено в техническую эксплуатацию на объектах электроэнергетической системы как альтернативный вариант применению традиционных дифференциальных токовых защит. Он обладает рядом преимуществ и позволяет решить существующие проблемы эксплуатации защит, обусловленные повышенными требованиями к измерительным трансформаторам тока в цепях дифференциальной защиты шин, необходимостью выполнения громоздких расчетов ее рабочих уставок, информационной избыточностью и сложностью современных цифровых устройств, выполняющих функцию дифференциальной защиты шин.

Ключевые слова: дифференииально-фазная защита шин, дифференциальная токовая защита шин, распределительная установка, сборные шины, релейная защита

Рекомендовано до публікаціі докт. техн. наук П. Д. Андрієнком. Дата надходження рукопису 17.06.18. 